Pål Kolstø. Kvasistater i internasjonal politikk. Nordisk Østforum, 2003, vol 17(2), 151-172.

Arkivert i DUO med tillatelse fra NUPI.

Lenke til NUPI http://www.nupi.no/

Lenke til tidsskriftet

http://www.nupi.no/publikasjoner/tidsskrifter/nordisk oestforum/ 


\section{Kvasistater i internasjonal politikk}

Pål Kolstø, universitet i Oslo

\section{'Quasi-states' og 'kvasi-stater'}

I 1990 utgav Robert H. Jackson en bok om Quasi-states: Sovereignty, International Relations and the Third World. ${ }^{1}$ Han påpekte at de fleste tidligere kolonier i Afrika som fikk uavhengighet på 1960- og -70-tallet, hadde et særdeles dårlig grunnlag for å kunne fungere som selvstendige stater. De hadde tidligere vært styrt som om de var et britisk county eller et fransk département, og manglet selv de mest nødtørftige institusjoner og infrastruktur. Enda mer problematisk var det at de ikke hadde eliter med tilstrekkelig utdannelse og erfaring til å overta styringen av staten. Koloniene hadde oppnådd uavhengighet ikke ved å oppfylle bestemte empiriske kriterier, men fordi det politiske klima hadde endret seg etter den andre verdenskrig: Kolonialisme var ikke lenger en gangbar politisk styreform, verken i verdensopinionen, i koloniene, eller for den saks skyld i kolonimaktene selv.

I tidligere århundrer var stater oppstått som følge av kriger og diplomati, påpekte Jackson. Stater som ikke var i stand til å forsvare seg, kunne i siste instans bli utradert fra kartet. I etterkrigstiden var dette radikalt forandret: alle de tidligere koloniene kunne regne med å overleve selv om de ikke oppfylte de kravene som må stilles for at en stat skal kunne fungere som en stat. I etterkrigstidens statssystem ble internasjonal

\footnotetext{
${ }^{1}$ Cambridge, Cambridge Univesity Press.
} 
anerkjennelse tildelt på et rent formelt, ikke-empirisk grunnlag. Dette har ført til at en helt ny type stater har oppstått, hevdet Jackson, nemlig 'quasi-states'. De holdes oppe av ytre støttepilarer, gjennom internasjonale konvensjoner og medlemskap i internasjonale organisasjoner, og ikke ved et indre reisverk av egne lover og institusjoner. Quasi-states hadde derfor kun 'negativ suverenitet', mente han.

Fenomenet 'negativ suverenitet' har viktige konsekvenser ikke bare for det internasjonale statssystem, men også for de nye statene selv. Statsledere i quasi-states skaffer seg sine største inntekter ikke ved å skattlegge befolkningen, som ofte har svært liten betalingsevne, men på to andre måter: ved å melke internasjonale giverorganisasjoner og ved å utnytte landets eksporterbare naturressurser. Mesteparten av disse inntektene finner veien ned i makthavernes egne lommer i stedet for å bli investert i statsbyggende eller samfunnsnyttige prosjekter. Forholdet mellom stat og samfunn, mellom leder og befolkning var derfor meget spinkelt. Ledere i 'quasi-states' trenger ikke støtte fra befolkningen for å holde seg ved makten. I stedet kjemper konkurrerende eliter om makten og kontroll over 'staten', eller rettere sagt: over retten til å presentere seg i utlandet som ledere for denne nærmest ikkeeksisterende størrelsen. De som blir anerkjent som statens ledere, vil kunne manipulere internasjonale giverorganisasjoner og med loven i hånd utnytte de ressursene som fantes i landet.

Jacksons bok utløste en viktig debatt om de postkoloniale statenes struktur og egenart og satte fingeren på et alvorlig problem i internasjonal politikk. Fremdeles brukes begrepet ' quasi-states' i akademisk litteratur ofte på den måten Jackson definerte dem. I journalistikk og politisk språkbruk ser det derimot ut til at hans terminologi ikke har 
slått igjennom. Her brukes i stigende grad andre uttrykk, så som 'shadow state', 'virtual state', og så videre for å beskrive de samme forholdene. Især har uttrykket 'failed states' vunnet frem i de senere år. Et søk på Google gav 1020 treff på 'quasistates' og hele 11,000 treff på 'failed states', og da hadde søket på 'quasi-states' fanget opp en hel del andre fenomener, som mikrostater (Monaco, Vatikanstaten), autonome enheter i føderale stater (Tatarstan, Burjatia), multinasjonale selskaper, og til og med en type kvasi-tilstand for visse atompartikler. Og endelig viste søket at begrepet 'quasi-states' i stigende grad blir brukt også på samme måte som 'kvasi-stater' blir brukt i dette spesialnummeret av Nordisk Østforum: som ikke anerkjente stater.

Denne terminologiske vaklingen er i utgangspunktet forvirrende og uønsket, men i denne artikkelen vil jeg bruke den som et utgangspunkt for å understreke en del viktige fellestrekk mellom 'quasi-states'. slik Jackson definerte dem, og kvasi-stater, slik vi definerer dem: I begge disse tilfellene dreier det seg om statsdannelser helt i utkanten av det internasjonale statssystem, og fenomener som stiller det internasjonale samfunn overfor spesielle problemer. I de aller fleste tilfeller har vi dessuten i begge kategorier også med særdeles svake stater å gjøre. Og endelig forholder Jacksons 'quasi-states' og 'våre' kvasi-stater seg til hverandre som årsak og virkning: 'Quasistates' er svært ofte for svake til å klare å opprettholde sin autoritet over hele sitt territorium effektivt. Dette gjør det mulig for politiske eliter i periferien å bryte løs fra sentralmyndighetenes kontroll og utrope sin provins som en kvasi-stat.

Samtidig er 'quasi-states' og 'kvasi-stater' ikke bare forskjellige, men i en viss forstand diametralt motsatte fenomener: 'Kvasi-stater' mangler nettopp den ene kvaliteten som ifølge Jackson 'quasi-states' er i besittelse av, den kvaliteten som i det hele tatt gjør at 
de fortsatt eksisterer, nemlig internasjonal anerkjennelse som selvstendig stat. ${ }^{2}$ Og til tross for at kvasistatene mangler dette, eksisterer de like fullt, noe som jo bør være et tankekors for 'quasi-states'-forskningen.

Svært lite har vært skrevet om kvasi-stater i betydningen ikke-anerkjente stater. Under forberedelsene til denne artikkelen forsøkte jeg å finne teoretisk og komparativ litteratur om dette emnet, men resultatet var magert. ${ }^{3}$ Denne artikkelen må derfor betraktes som noen første plogfurer i en nokså upløyd mark. De spørsmålene jeg håper å finne noen svar på er: Hvorfor oppstår kvasi-stater? Hva ønsker de å oppnå? Hvilke muligheter har de til å nå sine mål?

\section{Hvorfor oppstår og overlever kvasi-stater?}

Kvasi-stater finnes på de fleste kontinenter: i Europa, Afrika, og Asia, men ikke med samme tetthet overalt. Vi finner klart hyppigere forekomst av slike politiske størrelser i det tidligere Sovjetunionen og i den tidligere Jugoslavia, dvs. i to nylig oppløste multinasjonale, kommunistiske føderasjoner. I den tidligere sovjetrepublikken Moldova ligger den såkalte Dniester-republikken (PMR); i Sør-Russland finner vi

\footnotetext{
${ }^{2}$ Scott Pegg har bemerket at 'The quasi-state is legitimate no matter how ineffective it is. Conversely the de facto state is illegitimate no matter how effective it is.' Scott Pegg, 'The "Taiwan of the Balkans"? The De Facto State Option for Kosova', Southeast European Politics 1, December 2000, ss. 90-100, på s. 90. Med 'de facto State' mener Scott Pegg det samme som vi mener med 'kvasi-stat'.

${ }^{3}$ Det aller meste av den relevante litteraturen drøfter kun én konkret kvasistat. De eneste vitenskapelige artiklene som anlegger et komparativt perspektiv er Charles King, 'The Benefits of Ethnic War: Understanding Eurasia's Unrecognized States', World Politics 53, (July 2001), 524-52; Vladimir Kolossov and John O’Loughlin, 'Pseudo-States as Harbingers of a New Geopolitics: The Example of the Transdniestr Moldovan Republic (TMR) i D. Newman, ed., Boundaries, Territory and Postmodernity. London: Frank Cass, 1999, 151-176; Scott Pegg, International Society and the de Facto State, Aldershot: Ashgate, 1998, og Svante Cornells artikkel i dette nummer av Nordisk Øst-Forum.
} 
Tsjetsjenia, og i Azerbajdjan har Nagorno-Karabakh løsrevet seg. Georgia har den tvilsomme fornøyelse å være 'vertsland' for ikke mindre enn to kvasi-stater, nemlig Abkhazia og Sør-Ossetia.

I det tidligere Jugoslavia kan Kosovo på mange måter sies å fungere som en kvasistat. Republika Srpska hadde en tilsvarende status inntil den ble anerkjent som en entitet innenfor Bosnia-Hercegovina etter undertegningen av Dayton-avtalen i 1995. Samme år forsvant også en annen kvasi-stat i det tidligere Jugoslavia da Srpska Krajina i det østlige Kroatia ble rent overende av kroatiske styrker under operasjon 'Storm'. Makedonia var i realiteten også en kvasistat fra september 1991, da repubikken løsrev seg fra Jugoslavia, til april 1993, da den ble tatt opp i FN.

Siden avkoloniseringen har Afrika hatt minst fire kvasi-stater, hvorav én (Eritrea) har oppnådd internasjonal anerkjennelse, mens to (Katanga og Biafra) er blitt utradert, og én (Somaliland) fortsetter å eksistere som kvasi-stat. På grensen mellom Europa og Asia finner vi, i tillegg til Tsjetsjenia, og Den tyrkiske republikken på Nord-Kypros (TRNC). De kurdisk-kontrollerte områdene i Nord-Irak kan også sies å fungere som en kvasi-stat. I Burma har to områder, Karen og Shan, erklært seg som egen stat mens LTTE, 'De tamilske tigrene', i 1977 proklamerte uavhengighet for Tamil Eelam på den nordlige og østlige del av Sri Lanka. Taiwan er anerkjent av kun 28 stater, og inntar dermed en slags mellomstatus mellom en kvasi-stat og en 'vanlig' stat.

Denne listen over tidligere og nåværende kvasi-stater antyder at stater av denne typen frister en ytterst usikker tilværelse. De dukker opp og går til grunne igjen. Noen av dem må likevel kunne sies å ha oppvist en betydelig overlevelsesevne. Den eldste av 
dem, TRNC, ble opprettet i 1974 og har således eksistert sammenhengende i snart en generasjon. Det som krever en forklaring er derfor både hvordan noen av disse statene klarer å overleve og hvorfor noen går under.

Ettersom kvasi-stater ikke nyter den type internasjonal anerkjennelse som holder liv i andre svake stater, må det være noe annet som gjør det. Generelt sett kan vi snakke om to former for livredningsutstyr:

\section{Militcermakt}

Politiske formasjoner som ikke understøttes av det internasjonale system av gjensidig anerkjennelse mellom stater, blir i en viss forstand kastet tilbake til Hobbes' jungel. I enda større grad enn andre stater må de støtte seg på militærmakt for å overleve. Denne makten trenger likevel ikke være spesielt stor. Det er nok at kvasistaten kan hamle opp med det vi kan kalle utfordrerstaten, dvs. den (internasjonalt anerkjente) staten som gjør krav på samme territorium og som kvasi-staten har brutt ut fra. Disse utfordrerstatene er vanligvis svært svake. Charles King beskriver for eksempel Georgia, Moldova og Azerbajdjan, dvs. de statene som gjør krav på hhv. Abkhazia og Sør-Ossetia, PMR, og Nagorno-Karabakh, som 'exceptionally weak states' 'by any measure'. $^{4}$

Samtidig er det klart at kvasi-stater, av åpenbare årsaker, har en klar tendens til å bruke mye ressurser på oppbyggingen av det militære forsvaret.

En ekstern støttespiller.

\footnotetext{
${ }^{4}$ King, op. cit. s. 535.
} 
Selv med et relativt sterkt forsvar er mange kvasi-stater helt avhengige av støtte fra en ekstern støttespiller eller 'patron'. Med en mektig patron i ryggen kan en kvasi-stat i noen tilfeller være i stand til å holde ut selv overfor en forholdsvis sterk utfordrerstat. Dniester-republikken og Nord-Kypros nyter godt av støtte fra hhv. Russland og Tyrkia. I det første tilfellet er støtten uoffisiell: Russland har ikke anerkjent PMR, men uten aktiv støtte fra den russiske 14. arme i den moldoviske borgerkrigen i 1992 ville Dniester-republikken etter all sannsynlighet vært en saga blott i dag. Når det gjelder TRNC er støtten offisiell og direkte: Som det eneste land i verden har Tyrkia anerkjent diplomatisk sin datterrepublikk på Kypros, og har også tatt på seg store deler av det militære ansvaret for republikken.

Armenia fungerer som patron for Nagorno-Karabakh. Selv om Armenia selv er en meget svak stat som mange ganger har truet med å kollapse helt, er likevel forbindelseslinjen til Armenia gjennom Latsjin-korridoren den navlestrengen som holder liv i Nagorno-Karabakh. Armenia har ikke anerkjent Nagorno-Karabakh diplomatisk, men de tette forbindelsene mellom de to republikkene kommer klart til uttrykk, for eksempel i det forhold at Armenias nåværende president, Robert Kotsjarjan, kommer fra Nagorno-Karabakh og tidligere var president i denne kvasistaten.

Taiwan er en svært sterk stat størrelsen tatt i betraktning, ikke bare økonomisk, men også militært. Landet blir likevel som en puslete smågutt å regne sammenlignet med sin utfordrerstat, Folkerepublikken Kina. Fastlandskina ville utvilsomt forlengst ha hevet Taipei-regimet på sjøen dersom det ikke hadde vært for den militære støtte og sikkerhetsgaranti Taiwan får fra sin mektige patronstat, USA. 
Kosovo og de kurdisk-kontrollerte områdene i Nord-Irak utgjør spesialtilfeller ettersom den eksterne patron ikke er én bestemt stat, men hele det internasjonale samfunn representert ved FN. Den støtten de to områdene får, er av forskjellig art: I Nord-Irak dreier det seg om å nekte utfordrerstaten Irak muligheten til å gjenerobre området, mens den sivile administrasjonen overlates til lokale og ofte rivaliserende kurdiske grupper. I Kosovo, derimot, har FN gjennom UNMIK og KFOR i praksis overtatt ikke bare den militære kontrollen, men fører også nøye oppsyn med den sivile administrasjonen. Kosovo—i likhet med en annen del av det tidligere Jugoslavia: Bosnia-Hercegovina-blir i realiteten styrt som et internasjonalt protektorat. Det er likevel en vesensforskjell mellom disse to områdene: mens Bosnia-Hercegovina er en internasjonalt anerkjent stat og medlem av FN, kjemper Kosovo fortsatt en innbitt kamp for å oppnå en slik status.

\section{Overordnet målsetting for kvasi-stater: Internasjonal anerkjennelse.}

Ved hjelp av tilstrekkelig militær styrke kan kvasi-stater holde det gående i mange år og endog tiår. De befinner seg likevel konstant i en ytterst usikker situasjon, og muligheten for at staten til slutt vil bli utslettet er i høy grad til stede. I sterk kontrast til dette kan vi konstatere av anerkjente stater nyter noe i nærheten av full garanti for fortsatt eksistens, nærmest uansett hvordan de steller seg. Som Scott Pegg påpeker, 'once acquired, sovereign statehood has become almost impossible to lose. ${ }^{5}$ Siden FN

\footnotetext{
${ }^{5}$ Pegg, 'The Taiwan fo the Balkans', s. 90.
} 
ble opprettet i 1945 har ikke noen av dens medlemsstater blitt permanent ekskludert mot sin vilje. ${ }^{6}$

Derfor er det en helt overordnet målsetting for kvasi-stater å oppnå internasjonal anerkjennelse. Dette dreier seg ikke om økt prestisje og status, men om mulighetene for å overleve på sikt. Dette kan vi illustrere ved å sammenligne skjebnen til Srpska Krajina i Kroatia med Kuwait. Det irakske angrepet på Kuwait i 1990 og det kroatiske angrepet på Srpska Krajina i 1995 ble i de respektive utfordrerstatene oppfattet som samme type aksjoner: Det dreide seg i begge tilfeller om å gjenvinne kontroll over et område som urettmessig var blitt skilt ut fra staten. Det internasjonale samfunn derimot så det helt annerledes: Kuwait var og er en internasjonalt anerkjent stat mens Krajina ikke var det. Angrepet på Kuwait ble derfor ikke tålt, ment angrepet på Krajina ble stilltiende anerkjent.

Det internasjonale klima i etterkrigstiden har vært preget av svært strenge restriksjoner mot opprettelse av nye stater. ${ }^{7}$ Selv om prinsippet om nasjonenes selvbestemmelsesrett er nedfelt i FNs charter, blir det ikke oppfattet som om dette gir en del av et lands befolkning rett til å bryte ut og danne en egen stat. Prinsippet slår

\footnotetext{
${ }^{6}$ DDR ble strøket ved FNs medlemsliste i 1991, ikke mot befolkningens ønske, men som et resultat av en villet sammenslutning med Vest-Tyskland. Da det internasjonale samfunn i 1992 avgjorde at den jugoslaviske føderasjonen var oppløst ble restJugoslavia nektet retten til å overta denne statens plass i Generalforsamlingen. Jugoslavia kunne gjeninnta sin plass i FN først da landet søkte om nytt medlemskap som juguslavisk arvtakerstat i 2000.

Taiwan er et spesialtilfelle ettersom regimene i både Beijing og Taipei inntil det siste har gjort krav på å representere hele den kinesiske nasjon. Da de fleste vestlige land i løpet av 1970-tallet anerkjente kommunistregimet i Bejing, var det derfor ikke mulig å opprettholde anerkjennelsen av Formosa-regimet. Da Folkerepublikken overtok Taiwans plass i Sikkerhetsrådet, var det ikke snakk om å anerkjenne en annen stat, men et annet regime i samme stat.

${ }^{7}$ Öyvind Österud, 'The narrow gate: entry to the club of sovereign states', Review of International Studies 23, (1997), 167-84.
} 
fast at Folket har rett å styre seg selv ved å velge sine egne ledere til å styre staten, det gir derimot ikke noe grunnlag for å underminere eller splitte opp staten som sådan. Det er alminnelig antatt at dersom internasjonal anerkjennelse blir gitt til en eller noen få utbrytergrupper, vil det meget lett kunne føre til økt press fra andre grupper, med tiltakende fragmentering av statssystemet som resultat.

Dermed kan man si at statssystemet i prinsippet har vært lukket i begge ender: mens ingen er blitt kastet ut såsant de først er kommet innenfor er inngangsdøren har døren samtidig vært lukket for dem som står utenfor og banker på. Som Robert Jackson uttrykker det: 'There is international determination to retain the existing political map and to reject virtually out of hand any belated demands for self-determination, however worthy or just the cause may be. The conservatism of international society on this question is profound..$^{8}$ Det internasjonale systemet opererer etter Matteusprinsippet: 'Den som har, han skal få, og det i overflod. Men den som ikke har, skal bli fratatt selv det han har'. (Matt 25, 29)

Denne restriktive politikken har likevel ikke kunnet hindre en nærmest eksplosjonsartet utvidelse av FNs medlemsmasse, fra 51 medlemmer ved opprettelsen til 191 i dag. Én viktig årsak bak denne bemerkelsesverdige utvidelsen er at det internasjonale klimaet ved to anledninger er blitt endret. Tabuet mot opprettelse av nye stater er midlertidig blitt opphevet som en følge av at de aktuelle søkerstatene er blitt møtt med sterk internasjonal sympati. Dette skjedde første gang i perioden mellom midten av 1950-årene og midten av 1960-årene, da stemningen i de europeiske kolonimaktene skiftet fra imperiestolthet til moralsk fordømmelse av

\footnotetext{
${ }^{8}$ Jackson, Quasi-states, 190.
} 
kolonialismen. Med meget få unntak ville de tidligere koloniene ikke vært i stand til å riste av seg koloniåket med egen makt, Når de likevel oppnådde internasjonal anerkjennelse, hadde de ikke minst den vestlige opinion å takke for dette.

På 1990-tallet bidrog moralske hensyn for annen gang til at entredøren til den eksklusive klubb av anerkjente stater igjen ble åpnet. Denne gangen ble de nasjonaldemokratiske, separatistiske bevegelsene i Sovjetunionen og Jugoslavia møtt av en sterk bølge av forståelse og velvilje. Dette stemningsskiftet bidrog til at vestlige statsledere til slutt godtok at disse to statene smuldret opp.

De lærdommer dagens håpefulle statsledere kan trekke av etterkrigshistorien er for det første at forbudet mot statsopprettelse allikevel ikke så absolutt som det kan synes ved første øyekast. For det annet, at internasjonal sympati er en nødvendig om enn ikke tilstrekkelig betingelse for at dette forbudet skal bli satt ut av kraft.

I de to periodene da nye stater ble sluppet inn i statsfellesskapet, var dette helt klart ment som midlertidige og begrensede unntak fra regelen. I det første tilfellet skulle det omfatte kun oversjøiske kolonier og protektorater, mens andre grupper som i like høy grad følte at de var undertrykt av en fremmed nasjon, ikke ble inkludert. ${ }^{9}$ Avkoloniseringen gav dermed lille Palau (bef. ca. 19,000) rett til å bli en egen stat mens for eksempel kurderne med en befolkning på kanskje 20 millioner ikke har noen slik rett fordi deres undertrykkere ikke bor på andre siden av et hav. ${ }^{10}$

\footnotetext{
${ }^{9}$ Øyvind Østerud, Nasjonenes selvbestemmelsesrett, Oslo, Universitetsforlaget, 1984.

${ }^{10}$ Likevel var faktisk kurderne blitt lovet egen stat etter den første verdenskrig, et løfte som vestmaktene senere gikk tilbake på.
} 
I den andre perioden da man slapp noen nye stater inn i varmen, fant man et kriterium for å skille mellom verdige og uverdige kandidater i Sovjetunionens egen grunnlov. Alle de 15 unionsrepublikkene hadde hatt en grunnlovfestet rett til å tre ut av staten dersom de skulle ønske det. Når de nå rev seg løs, gjorde de altså ikke annet enn å benytte seg av en rett som kommunistlederne selv hadde gitt dem. Det forhold at statsoppløsningen stred mot flertallets ønske slik det ble uttrykt i en folkeavstemning våren 1991, ble ikke oppfattet som tungtveiende nok til å nekte dem dette.

De jugoslaviske republikkene hadde ikke hatt noen tilsvarende formell rett til løsrivelse, noe som stilte det internasjonale samfunn overfor vanskelige avveininger. EUs Arbitration Commission ble bedt om å uttale seg og slo i januar 1992 fast at Jugoslavia på det tidspunkt allerede var 'in the process of dissolution'. ${ }^{11}$ Dette synet ble godtatt også av FN og på det grunnlaget ble de tidligere jugoslaoviske republikkene anerkjent, først Slovenia, Kroata og Bosnia-Herzegovina, (1992) og til slutt Makedonia (1993).

Dagens kvasi-stater trekker paralleller mellom sin situasjon og begge de to etterkrigsperiodene da nye stater ble opprettet. De presenterer for det første proklameringen av sin egen stat som et tilfelle av avkolonisering. Ikke minst tsjetsjenske talsmenn fremstiller regelmessig sin sak som et tilfelle av forsinket avkolonisering og dette synspunktet aksepteres av mange vestlige forskere og menneskerettighetsorganisasjoner. ${ }^{12}$ Armenske aktivister for sin del hevder at

${ }^{11}$ Gnanapala Welhengama, Minorities' Claims: From Autonomy to Secession. International Law and state practice. Aldershot: Ashgate 2000, s. 250.

${ }^{12}$ See e.g. 'Chechens appeal to Council of Europe to end Russian "colonization".' 15 August 2001, online på http://tchetchenieparis.free.fr/text/Chechens-appeal-15-801.htm; og Märta-Lisa Magnusson, 'The International Community and Strategies for 
opprettelsen av Nagorno-Karabakh var 'the first instance in the second tier of decolonization of the Soviet Union'. ${ }^{13}$

For det andre har de fleste av dagens kvasi-stater i det post-sovjetiske Eurasia tidligere vært en føderal enhet i Sovjetunionen, men på et lavere nivå enn Unionsrepublikkene: Nagorno-Karabakh, Abkhazia, og Tsjetsjenia hadde alle vært Autonome republikker, mens Sør-Ossetia hadde vært et Autonomt område (oblast). Det fantes ikke noen Autonom Dniester republikk i Moldova på den tiden da området øst for Dniester-elven rev seg løs, men det hadde eksistert en moldovisk autonom sovjetisk sosialistisk republikk (MASSR) på omtrent samme område mellom 1924 og 1940, og dagens myndigheter i PMR hevder at de har gjenetablert denne enheten. I Jugoslavia hadde Kosovo på en tilsvarende måte også vært en egen føderal enhet men på et lavere nivå enn republikkene: Det hadde vært en autonom provins innen den serbiske republikken, og siden 1974 hadde det hatt nesten samme rettigheter som republikkene.

Det internasjonale samfunnet har likevel nektet å anerkjenne en føderal status på lavt nivå i den sovjetiske eller jugoslaviske føderasjonen som legitimt grunnlag for løsrivelse. I det sovjetiske tilfellet skyldes dette at de føderale enheter på lavere nivå ikke hadde noen grunnlovfestet rett til å trekke seg ut av staten, slik unionrepublikkene hadde. Selv om denne argumentasjonen er konsistent og formelt sett korrekt er det likevel noe ironisk at den sovjetiske konstitusjonen på denne måten

Peace and Stability in and around Chechnia: Comments on Contributions', online på http://www.caucasus.dk/publication7.htm. Et Google søk på ordene 'Chechnya + decolonization' gav over 800 treff.

${ }^{13}$ Nagorno Karabagh: A White Paper, Yerevan: The Armenian Center for National and International Studies, 1997, 20. 
gis en status som dørvakt ved inngangsporten til den internasjonale klubb av anerkjente stater, og det på et tidspunkt da denne grunnloven ellers er grundig diskreditert og forlengst passé. De postssovjetiske kvasi-statene argumenterer for øvrig med at dersom sovjetisk lovgiving fremdeles skal regnes som gyldig, da bør man også ta hensyn til den sovjetiske loven som ble vedtatt i 1990 for å regulere spørsmål vedrørende utmeldelse av staten. Denne loven gav autonome republikker og autonome områder en rett til selv å avgjøre sin fremtidige status gjennom en folkeavstemning dersom den unionsrepublikken de sorterte inn under skulle bestemme seg for å tre ut av USSR. ${ }^{14}$ Når det gjelder Kosovo er det enda vanskeligere å finne noen prinsipielle grunner til å nekte anerkjennelse når slik anerkjennelse først er gitt til de andre føderale enhetene i det tidligere Jugoslavia. ${ }^{15}$

Også i andre deler av verden viser kvasi-statledere til tidligere politiske eller administrative grenser i området for å underbygge sin rett til å danne egen stat. Eritrea var en egen koloni, først under italienerne og dernest under britene, før området ble slått sammen med Etiopia i 1952. Eritreiske ledere baserte sin mer enn 25 år lange kamp for selvstendighet på denne omstendigheten, og oppnådde internasjonal anerkjennelse i 1993. På den andre siden av Afrikas horn har Somaliland hevdet at dette området burde få rett til å tre ut av Somalia siden Somaliland hadde vært en egen britisk koloni frem til 1960. Somaliland hadde til og med eksistert som egen stat en kort stund, riktignok bare fem dager, før det ble slått sammen med Somalia. Dette argumentet har så langt ikke gjort inntrykk på verdenssamfunnet og det er i disse

\footnotetext{
${ }^{14}$ Dette argumentet brukes blant annet av Nikolay Hovhannisyan, i The Karabakh Problem:Factors, Critieria, Variants of Solution, Yerevan: Zangak97, 1999, 43. ${ }^{15}$ Se f.eks. betenkningen 'Intermediate Sovereignty As A Basis For Resolvning The Kosovo Crisis' fra The Public International Law and Policy Group i The International Crisis Group, online på http://archiv.medienhilfe.church/Projekte/KOS/Reports/icgkosov@.html.
} 
tilfellene unektelig noe ironisk at de gamle kolonigrensene, som vi vanligvis oppfatter som svært vilkårlige, gjennom slike argumenter gis avgjørende og legitimerende kraft.

\section{Kvasi-staters utenrikspolitikk}

Som et ledd i sine bestrebelser på å oppnå internasjonal anerkjennelse har noen kvasistater sluttet seg til Unrecognized Peoples and Nations Organization (UNPO). Denne organisasjonen etteraper FN i navn, charter og sin generelle språkbruk. Dens charter slår fast at, 'All peoples have the equal right to self-determination.The right to selfdetermination includes the right to independent statehood where the exercise of the right to self-determination cannot be implemented without establishing an independent state. ${ }^{16}$ Abkhazia, Kosovo, Nord-Irak, Tsjetsjenia og Taiwan er alle medlemmer av UNPO, og Litauen og Øst-Timor er tidligere medlemmer. De to siste statenes skjebne antyder overfor de andre at medlemskap i denne organisasjonen kan være en farbar vei for å oppnå internasjonal anerkjennelse.

Forbausende mange kvasi-stater har likevel ikke sluttet seg til UNPO. Man leter forgjeves etter navn som Sør-Ossetia, Nagorno-Karabakh eller Dniester-republikken på UNPOs medlemsliste. Det kan tyde på at en del kvasistatledere oppfatter medlemskap her som en blindvei. Det kan lede dem inn på et permanent B-lag blant verdens stater og nasjoner.

En alternativ strategi for kvasi-stater for å oppnå anerkjennelse er å begynne å opptre mest mulig 'som om' de allerede var anerkjent. Elementer av en slik 'als ob'-strategi finner vi i de fleste kvasi-staters selvpresentasjon. Den tsjetsjenske grunnloven slår for

\footnotetext{
${ }^{16}$ http://www.unpo.org/news/news2002may-jul/universal_declaration.htm.
} 
eksempel fast at Den tsjetsjenske republikken er 'an independent sovereign state ... recognizing itself as an equal subject in rights within the system of the world commonwealth of nations... ${ }^{17}$ Så lenge de ikke er anerkjent av andre begynner tsjetsjenerne med å anerkjenne seg selv. Den Tyrkiske Republikken på Nord-Kypros erklærer at den akter å 'play an active role in efforts aimed at promoting international understanding and cooperation as well as respect for the fundamental rights and freedoms of all mankind, despite being denied the right to be represented at almost all international fora'. ${ }^{18}$ Den abkhaziske republikken for sin del 'intends to build up its relations with other States on the basis of equality, peace, good-neighbourly relations, respect for territorial integrity and sovereignty, non-interference in internal affairs, and other universally recognized principles of political, economic and cultural cooperation between States. ${ }^{19}$

Alle kvasi-stater har sitt eget Utenriksdepartement, (noen gang under et litt annet navn) som tar seg av forholdet til andre stater. Disse departementene har vanligvis under seg et nettverk av 'Permanent representatives abroad', men med unntak av Nord-Kypros' ambassade i Ankara dreier dette seg om informasjonskontorer og andre former for ikke-diplomatisk representasjon. Disse kontorene blir tolerert men ikke offisielt anerkjent av vertslandet. $^{20}$

${ }^{17}$ http://www.chechenpress.info/english/attributes/constitutions.htm.

18 'Foreign policy, defense and representation abroad', http://www.trncwashdc.org/org/g006.html.

19 'Act of State independence of the republic of Abkhazia', http://www.apsy.org/index_t.html.

${ }^{20}$ Til tider er det likevel nesten bare navnet som skiller. USA har f.eks. noe som minner sterkt om normale diplomatiske forbindelser med Taiwan gjennom the American Institute in Taiwan, AIT. 
Uten tilgang til normale diplomatiske kanaler forsøker kvasi-statene å nå ut til verdensopinionen ved å opprette sine egne hjemmesider på nettet. Internett er som kjent særdeles demokratisk, noen vil si anarkistisk. Det kreves ingen tunge investeringer eller avansert teknisk kompetanse for å opprette en hjemmeside, og slett ingen offisiell godkjennelse. Det er vanskelig å vurdere hvor effektivt dette diplomatiet i cyberspace er, men hjemmesiden til Nagorno-Karabakh republikken møter i alle fall sine lesere med følgende velkomsthilsen: : 'Having a site is of special importance to our young state striving for international recognition.... We are interested in every new visitor, because like many other foreign offices, our site, in essence, serves as a virtual embassy'. ${ }^{21}$ Ordspillet mellom 'virtual embassy' i betydningen 'ambassade på internett' og 'virtual embassy' som 'nesten-ambassade' eller 'liksom-ambassade' er åpenbart utilsiktet.

En annen konsekvens av internetts anarkiske karakter er imidlertid at det ikke finnes noen form for autentisitetskontroll. Det betyr at andre operatører der ute kan kidnappe navnet på din kvasi-stat og bruke det for sine egne formål. Den som for eksempel søker etter sider om Abkhazia på Google vil først bli ledet til www.abkhazia,ge. Denne siden presenterer seg som 'the website of the Legitimate Government of the Autonomous Republic of Abkhazia.' Det er først når man går inn på denne siden og begynner å lese om for eksempel 'The horrors of Abkhaz separatism' at man forstår at man kanskje ikke er kommet helt dit man trodde. Det viser seg at denne siden drives av en gruppe som representerer georgiske flyktninger fra Abkhazia i Georgia.

${ }^{21}$ http://www.nkr.am/eng/ 
I det alt vesentlige må man kunne slå fast at lederne for kvasi-stater ikke har lyktes i å vekke verdenssamfunnets sympati for sin sak. Verken Sør-Ossetia, Abkhazia, Nagorno-Karabakh eller PMR--for ikke å snakke om Somaliland - vekker noen sterke følelser i den offentlige opinion i den vestlige verden. Folk flest har ganske enkelt ikke hørt om dem. I så henseende er Tsjetsjenia i en annen situasjon. Den tsjetsjenske konflikten kan ikke avfeies som 'a quarrel in a far-away country among people of whom we know nothing', (slik den britiske statsministeren en gang omtalte Tsjekkoslovakia.) I motsetning til konfliktene i andre kvasi-stater, der partene nok har bemannede vaktposter men ikke lenger skyter på hverandre, blir Tsjetsjenia-krigen fremdeles utkjempet på bakken, med blodige tap på begge sider. Denne konflikten er derfor i høyeste grad i stand til å ryste opinionen i vestlige land, men sympatien går ikke alltid i retning av tsjetsjenerne og deres sak. I Europa, og deriblant også i Norge, er det nok en tendens til å fordømme i første rekke de klare overgrep og menneskerettighetsbrudd som blir begått av russiske hærstyrker, mens amerikanske medier har en sterkere tendens til å fokusere på forbindelsene mellom tsjetsjenske grupper og internasjonale terrornettverk, deriblant Al Qaida.

\section{Aktiv nasjonsbygging}

I dagens verden presenterer alle stater seg som 'nasjonalstater'. De unntakene som finnes, så som fyrstedømmene Liechtenstein og Monaco, er så få at de bidrar til å bekrefte denne regelen. Alle statsledere hevder med rette eller urette å representere sin 'nasjon', og dette gjelder også for kvasi-stater. Kvasistatledere taler på vegne av det ossetiske folk, det somalilandske folk, det dniesterske folk, og så videre. Abkhazia, for eksempel, appellerer til FN, OSSE og alle verdens Stater om å 'anerkjenne den 
uavhengige Stat som Abkhazias folk har dannet på basis av nasjonenes frie rett til selvbestemmelse. $^{.22}$

Som alle andre stater driver kvasi-stater med aktiv nasjonsbygging i den forstand at de iherdig forsøker å inngi alle statens innbyggere en følelse av skjebnefellesskap og overgripende felles identitet knyttet til staten. Mens kvasi-statenes utenrikspolitikk tar sikte på å skaffe regimet støtte utenfra, er nasjonsbyggingen rettet inn mot å bygge opp støtte innenfra.

Siden alle kvasi-stater har løsrevet seg fra en annen stat som fortsetter å gjøre krav på samme område og samme befolkning, har kvasi-statenes nasjonsbygging et negativt så vel som et konstruktivt aspekt. På den ene side må den undergrave utfordrerstatens påstand om at kvasi-statens befolkning 'egentlig' tilhører en annen (=utfordrerstatens) nasjon, på den annen side må kvasi-statlederne med forskjellige midler gi form, innhold og troverdighet til sin egen, rivaliserende nasjonstanke.

I noen tilfeller, som Somaliland, Taiwan og i noen grad også PMR, finnes det sterke bånd mellom utfordrerstatens og kvasi-statens befolkning av kulturell, historisk og/eller etnisk karakter, og dette kompliserer den mentale løsrivelsesprosessen. I andre tilfeller finnes det en langt sterkere egen identitet knyttet til kvasi-statens territorium og egenart. Endelig finnes det en tredje type tilfeller der en i utgangspunktet svak identitetsgrense mellom majoritetsbefolkningen i utfordrerstaten og kvasi-statens innbygger er blitt forsterket gjennom krig, befolkningsutvekslinger og nasjonsbygging.

\footnotetext{
22 'Act of State independence of the republic of Abkhazia', http://www.apsny.org/index_t.html.
} 
Da PMR løsrev seg, på begynnelsen av 1990-tallet, var moldovisk politikk dominert av den sterkt etno-nasjonalistiske Moldoviske Folkefronten og Moldova ble proklamert som moldovernes nasjonalstat. I bevisst opposisjon til dette la Dniesterrepublikken til grunn et erklært ikke-etnisk nasjonsbegrep for sin ubryterstat. PMR har derfor ikke mindre enn tre offisielle språk—moldovisk, russisk og ukrainsk, dvs. språket til de tre største gruppene i området. Sammen med de mindre etniske gruppene som bor der, utgjør de 'Dniesters multinasjonale folk. ${ }^{23}$

I de fleste tilfellene er likevel grunnlaget for også kvasi-statens nasjonsbegrep klart etnisk. Dette gjelder for eksempel Den tyrkiske republikken på Nord-Kypros. Den ble etablert som et fristed for etniske tyrkere som flyktet fra diskriminering og undertrykkelse fra den gresk-kypriotiske majoritetsbefolkningens side. I NagornoKarabakh er i dag så godt som hele befolkningen armensk mens utfordrerstaten Azerbajdjan representerer armenernes tradisjonelle fiende, tyrkerne. På slutten av 1980-tallet fant det sted etniske pogromer på armenere i en rekke azerbajdzjanske byer som utløste omfattende befolkningsutvekslinger mellom Azerbajdjan på den ene side og Nagorno-Karabakh og Armenia på den annen. Som en følge av dette er i dag så godt som hele befolkningen i Nagorno-Karabakh etniske armenere.

Mens alle stater, nye så vel som gamle, driver aktiv nasjonsbygging, er slik aktivitet likevel spesielt viktig for nye stater med en foreløpig svakt utviklet fellesidentitet. Jo mer tvilsom påstanden om at statens befolkning utgjør en egen nasjon lyder, jo mer

\footnotetext{
${ }^{23}$ Pål Kolstø, Andrei Edemsky og Natalya Kalashnikova, 'The Dniester Conflict: Between Irrendentism and Separatism', Europe-Asia Studies 45, (no. 6 1993), 9731000; Pål Kolstø og Andrei Malgin, 'The Transnistrian republic: A Case of politicized Regionalism’, Nationalities papers 26, no. 1, (Mars 1998), 103-128.
} 
krefter og større oppfinnsomhet må lederne bruke for å overbevise befolkningen om at det forholder seg slik. ${ }^{24}$ Alle kvasi-stater har sitt eget statsflagg, sin nasjonalsang, sitt riksvåpen og andre statsattributter. Nye nasjonale helligdager og festdager feirer nasjonens kultur og historie. Det bygges museer og statuer til minne om nasjonens store sønner (og kanskje noen få døtre) og gater oppkalles etter disse. Av og til bygges det også opp en personlighetskult rundt kvasi-statens nåværende leder. Et eksempel på dette er opphausingen av den i utgangspunktet relativt fargeløse teknokraten Igor Smirnov som man kan observere i Dniester-republikken i dag. ${ }^{25}$

De fleste kvasi-stater trykker sine egne frimerker og pengesedler, eller mer korrekt: får dem trykket for seg i utlandet. Disse tjener flere formål: Siden alle normale stater har sine egne frimerker og penger, gir det å trykke slike et inntrykk av at kvasi-staten er en 'normal' stat. Dernest kan frimerker og pengesedler brukes til å feire nasjonens helter og stolte øyeblikk i fortiden (sml. rekken av statsmenn, vitenskapsmenn og kunstnere på norske pengesedler.) Slik sett er også dette virkemidler i identitetsbyggingen.

Nagorno-Karabakh begynte å gi ut frimerker allerede i 1993, og snart fulgte Abkhazia, Sør-Ossetia og Tsjetsjenia etter. Frimerker som utgis av kvasi-stater vil imidlertid ikke kunne fylle en av frimerkenes hovedfunksjoner, nemlig å formidle brev til og fra utlandet. De land som har undertegnet Verdens postkonvensjon, og det er de aller fleste, har kun lov til å viderebefordre brev med frimerker utstedt av land

\footnotetext{
${ }^{24}$ Pål Kolstø, 'Nation-building in the Former USSR', Journal of Democracy 7, January 1996, 118-132; og Pål Kolstø, Political construction sites. Nation-building in Russia and the post-Soviet States. 2000 (Boulder, Colorado: Westview press, 2000). ${ }^{25}$ Stefan Troebst, "'We Are Transnistrians!” (Post-)Soviet Identity Management in the Dniester Valley', Ab Imperio, March 2003.
} 
som er medlemmer av The Universal Postal Union. Ikke-anerkjente frimerker kan derfor lett komme til å ha motsatt effekt av det utstederne ønsker seg, nemlig å understreke kvasi-statens internasjonale isolasjon.

I endel tilfeller aksepterer patron-staten frimerker utstedt av sin klient-stat. Dette gjelder rimeligvis for Nord-kypriotiske frimerker i Tyrkia, mens russiske myndigheter i 1995 innskjerpet overfor sine lokale postkontorer at de ikke skal viderebefordre brev med sydossetiske, abkhaziske eller dniestrianske frimerker. En russisk filatelist på besøk i Syd-Ossetia i 2001 sendte likevel et brev med et lokalt frimerke hjem til seg selv, og det kom frem. ${ }^{26}$

Det finnes ingen objektiv målestokk for å avgjøre om et nasjonsbyggingsprosjekt er vellykket eller ikke. Selv ledet jeg i 1995-98 et forskningsteam som blant annet undersøkte etniske og nasjonalstatlige identiteter i Moldova og Dniester-republikken. En meningsmåling blant ca. 200 respondenter i Dniester-republikken indikerte at innbyggerne her i betydelig grad var fremmedgjorte i forhold til den moldoviske staten og i stedet identifiserte seg med PMR som sin 'nasjonalstat'. ${ }^{27}$ Resultatene av slike meningsmålinger vil imidlertid alltid være åpne for ulike tolkninger. De som vil trekke dem i tvil, kan f.eks. hevde at respondentene har vært utsatt for press eller indoktrinering fra de kvasistatlige myndighetenes side. Mot dette argumentet kan det selvfølgelig anføres at dersom indoktrinering eller propaganda får folk til å slutte opp

\footnotetext{
${ }^{26}$ Paul Goble, 'Russia: Analysis from Washington-Stamps and Statehood', online at http://www.rferl.org/nca/features/2001/04/1004200111241.asp.

${ }^{27}$ Kolstø, National integration, op. cit (fn. 4); Stefan Troebst, "'We Are Transnistrians!” (Post-)Soviet Identity Management in the Dniester Valley', Ab Imperio, March 2003,
} 
om staten, er dette i seg selv en indikasjon på vellykket nasjonsbyggingen:

propaganda er jo nettopp et viktig virkemiddel i nasjonsbyggingen.

Jeg vil uansett våge å fremsette den påstand at den nasjonalstatlige konsolidering, ikke bare i Dniester-republikken men i de fleste kvasi-stater, er nådd langt.

Befolkningen i disse områdene har etter min oppfatning en høy grad av felles identitet som nasjon. Denne konklusjonen bygger ikke på et omfattende empirisk materiale, men mer på et logisk resonnement omkring identitetsbygging, og da især rundt en antakelse om hvordan krig påvirker identitetsdannelse. For det er nok i første rekke den borgerkrigen som i de fleste tilfeller ble utløst av forsøket på å bryte ut av staten, som har skapt en sterk fellesskapsfølelse, mer enn regimets bevisste nasjonalitetspolitikk.

I likhet med hva som er tilfelle i de fleste stater finnes det også i mange kvasi-stater sterke regionale, ideologiske og etniske splittelser, men så lenge utfordrerstaten fortsetter å gjøre krav på sitt tapte territorium, vil de sentripetale kreftene i kvasistaten være sterkest. Forestillingen om Den Felles Ytre Fiende fungerer som en sterk motor bak den nasjonale samlingsprosessen i utbryterregionen. På den måten bidrar utfordrerstaten ironisk nok til å konsolidere den utbryternasjonen som den innbitt hevder ikke eksisterer. ${ }^{28}$ Den delen av utbryterregionens befolkning som ikke identifiserer seg med kvasi-staten, vil ofte ha flyktet til moderstaten. Dermed bidrar også de til å gjøre kvasi-statens befolkning mer homogen, i ideologisk, kulturell og som regel også etnisk forstand.

\footnotetext{
${ }^{28}$ Noen utfordrerstater er villige til å innrømme at befolkningen i utbryteregionen utgjør en egen regional eller etnisk undergruppe, men ingen godtar påstanden om at de representerer en egen regions. Som det står på f.eks. hjemmesiden til de georgiske flyktningene fra Abkhazia: "Abkhaz and Georgians are the same”.
} 
Det faktum at kvasi-staten, ved sin blotte eksistens, kan sies å ha vunnet borgerkrigen, øker dens muligheter til å utnytte krigsminnene til nasjonsbyggende formål. En seierrik krig er vanligvis mer minneverdig enn et forsmedelig tap. PMR har gitt ut en serie bøker og brosjyrer om 1992-krigen, deriblant en egen minnebok over de 457 dniestrianerne som døde, med navn, bilde og personlige opplysninger om hver enkelt av dem. ${ }^{29}$ PMR, Nagorno-Karabakh og andre kvasi-stater har også innstiftet en rekke medaljer og ordner for tapperhet og fortjeneste for Fedrelandet. Noen av disse medaljene er tildelt heltemartyrene posthumt. De stadige påminnelsene om borgerkrigen understreker også den uvurderlige rolle de væpnede styrker spiller for statens eksistens og overlevelse. Dette bidrar til å øke offiserenes prestige og innflytelse i samfunnet.

\section{Mangelfull statsbygging}

Det kan være fruktbart å innføre et skille mellom nasjonsbygging og statsbygging. Med nasjonsbygging mener vi da slike 'myke' sider ved statskonsolidering som de jeg har drøftet i det foregående, De tar sikte på å forme en felles nasjonalstatlig identitet for landets befolkning ved hjelp av propaganda, statssymboler, nasjonale helligdager osv. Med uttrykket statsbygging derimot sikter vi til 'harde' aspekter som institusjonsbygging og oppbygging av et økonomisk fundament og et militært forsvar for landet. Lover må vedtas og håndheves, grensene må sikres, staten må skaffe seg et monopol på legitim voldsbruk gjennom ordensmakten; det må utarbeides regler og prosedyrer for innsamling av skatt, for regulering av handel og næringsvirsomhet, osv.

${ }^{29}$ Kniga pamiati zashchitnikov Pridnestrov'ia, Tiraspol: forlag ikke angitt, 1995. 
Samtidig som alle kvasi-stater kan vise til betydelige suksesser når det gjelder nasjonsbygging, er deres resultater når det gjelder statsbygging langt mer beskjedne. Et raskt blikk på noen av de lovene og grunnlovene som de postsovjetiske kvasistatene har vedtatt, gir en indikasjon på at det kan være stor avstand mellom proklamasjoner og den faktiske, effektive institusjonsbyggingen. Disse grunnlovene er ofte svært omstendelige og detaljerte dokumenter som knesetter alle grunnleggende menneskerettigheter, så som tale-, forsamlings- og trykkefrihet, religionsfrihet, hjemmets ukrenkelighet, osv. osv. Postsovjetiske kvasi-stater har også en klar tendens til å garantere vide sosiale rettigheter for sine borgere, på samme måte som Sovjetunionen gjorde det. Svært ofte lyder imidlertid disse garantiene lite overbevisende. Det kan nesten virke som om det er et omvendt proporsjonalt forhold mellom hvor mange og sterke sosiale garantier som utstedes, og statens evne og vilje til å oppfylle sine løfter.

Den tsjetsjenske republikken har tilsynelatende vedtatt en meget forpliktende grunnlov. Den slår fast at

the systems of free, qualified public healthcare, social maintenance, public education, culture and sport are perfected in the Chechen republic... The Chechen republic cares for the development of science, art, literature, public 
creativity, creates the conditions for the rise of intellectual, spiritual and moral levels of the population. ${ }^{30}$

Dette er langt mer omfattende løfter enn de fleste vestlige velferdsstater er beredt til å fremsette. Når de tsjetsjenske myndigheter ikke engang er kommet i nærheten av å oppfylle dem, kan de nok vise til den langvarige og ødeleggende krigen som én forklaring. Men det er likevel klart at både før utbruddet av den første Tsjetsjeniakrigen i 1994 og i pausen mellom den første og den andre Tsjetsjenia-krigen var det ikke mange tsjetsjenske borgere som ville kjent seg igjen i denne beskrivelsen av det samfunnet de levde i.

Noen kvasi-stater fungerer bedre enn andre. Når det gjelder for eksempel PMR har Vladimir Kolossov og John O'Loughlin hevdet at

Eight years after the declaration of sovereignty, [PMR] has all the attributes of a normal state, except for international recognition. These characteristics include a constitution adopted by referendum, an elected parliament and president, formal government, a system of security (police, an army of 5,000 to 7,000 men, and customs services), a system of elected local administration, and a (weak) currency. ${ }^{31}$

Charles King deler tilsynelatende denne oppfatningen. Han har skrevet at 'political elites in each region [postsovjetisk kvasi-stat] have managed to build states that now

\footnotetext{
${ }^{30}$ The constitution of the Chechen republic, http://www.chechenpress.info/english/attributes/constitutions.htm.

${ }^{31}$ Kolossov and O’Loughlin, 'Pseudo-States', s. 167.
} 
function about as well as the recognized countries of which they are still formally constituents'. ${ }^{32}$ Men som jeg har påpekt tidligere i denne artikkelen betrakter King de postsovjetiske kvasi-statenes moderstater som 'exceptionally weak'. Dermed ser det ikke ut til at han har så høye tanker om resultatene av kvasi-statenes statsbygging likevel. Det virker tvert imot som om han er mer enig med Charles Fairbanks som har hevder at kvasi-statene er 'the weakest of the weak states'. ${ }^{33}$

En svak stat kan være resultat av små ressurser og/eller liten statsbyggende innsats. Det er helt klart at svært mange kvasi-stater har et dårlig økonomisk utgangspunkt. Kosovo var den fattigste regionen i Titos Jugoslavia, og Tsjetsjenia, NagornoKarabakh og Sør-Ossetia var alle svært tilbakeliggende regioner i Sovjetunionen. I Abkhazia og Dniester-regionen var situasjonen en annen. Begge disse områdene hadde en høyere levestandard enn gjennomsnittet i den republikk de lå inn under, hhv. Georgia og Moldova. Krajina inntok en mellomposisjon. Denne utbryterstaten omfattet både lite utviklede områder i selve Krajina samt langt mer velstående områder i Øst-Slavonia, der det blant annet var oljeforekomster.

Samtidig har flere forskere ment at svak statsmakt ikke nødvendigvis er naturgitt, men kan også i høy grad være resultat av en villet politikk. Robert Jackson mener at ledere i 'quasi-states' mangler incentiver for effektiv statsbygging ettersom de kan oppnå makt og personlig rikdom uten å styrke staten. William Reno har skjerpet denne tesen ved å hevde at i ekstreme tilfeller utvikler 'quasi-states' seg til 'shadow states'. I slike 'stater' har lederne et positivt incitament til å ødelegge det som fortsatt måtte eksistere

\footnotetext{
${ }^{32}$ King, 'Benefits of ethnic war,' s. 535.

${ }^{33}$ Charles Fairbanks, 'Weak states and Private Armies,' i Beissinger og Young, Beyond State Crisis?, s. 141.
} 
av statsstrukturer. 'From the ruler's perspective, officials or local organizations who appropriate resources and tasks nominally allocated to the state could easily curtail the ruler's authority if they were even modestly effective at providing a basic service. Thus rulers who do not offer postal services jealously guard the unfulfilled prerogatives of state sovereignty. ${ }^{34}$

De aller fleste kvasi-stater--slik vi bruker begrepet i dette nummeret av NØF--har ikke sunket ned på skyggestatens nivå, men enkelte kommer likevel farlig nær. Kvasistater med skyggetendenser har en uforholdsmessig stor svart økonomi, ofte med tette bånd til ledere på høyt nivå i staten. Som Svante Cornell påpeker i sin artikkel, er denne svarte økonomien basert på smugling, ulovlig våpensalg, produksjon av falske merkevarer, handel med narkotika og prostituerte, osv. Lokale embetsmenn og politikere tjener på denne virksomheten gjennom bestikkelser og beskyttelsespenger, mens kvasi-staten som sådan ikke har noen inntekter fra den. Den 'skatt' som inndrives på denne måten går i private lommer i stedet for i statskassa. Dette er selvsagt et velkjent fenomen i mange land, også i den vestlige verden, men visse omstendigheter gjør dette til et mer omfattende og alvorlig problem i kvasi-stater enn i anerkjente stater. Siden kvasi-staten ikke er internasjonalt anerkjent kan ingen mellomstatlige konvensjoner eller avtaler gjøres gjeldende i området, og det internasjonale samfunn har svært begrensede muligheter til å overvåke kvasi-statenes indre liv, politisk så vel som økonomisk og rettslig. Denne mangelen på transparens virker som det reneste fluepapir på kriminelle og andre lyssky elementer.

\footnotetext{
${ }^{34}$ William Reno, 'Mafiya Troubles, Warlord Crises', i Beissinger og Young, Beyond State Crisis?, s. 110.
} 


\section{Kvasi-statenes fremtid}

Mens noen kvasi-stater har oppvist en imponerende seiglivethet, må slike statsdannelser likevel kunne betraktes som overgansfenomener. Med høy grad av sannsynlighet vil de aller fleste av dem forsvinne igjen før eller siden. Dette kan skje på en av fire måter.

Gjenerobres av utfordrerstaten.

Dette skjedde med Katanga i 1965, Biafra i 1970 og Krajina i 1995. Vestlig kritikk av kroatenes 'Operasjon Storm' har vært påfallende svak til tross for at den utløste en massiv, frykt-basert flyktningestrøm av lokale serbere som har mange likhetstrekk med palestinernes flukt fra israelsk fremrykking under den arabisk-israelske krig i 1948.

Inkorporeres i den eksterne patron-staten.

Politiske ledere i både Nagorno-Karabakh og på Nord-Kypros hevder bestemt at de ikke søker å bli innlemmet i sine respektive patronstater, og den samme beskjeden vil man få i Jerevan og Ankara. Det synes likevel klart at for disse landene er et slikt utfall den foretrukne løsningen. Visse grupper også i Dniester-republikken arbeider for at PMR skal innlemmes i denne kvasistatens patron-stat, Russland. De viser gjerne til at Kaliningrad-oblasten allerede er geografisk skilt fra resten av Russland og mener det må være mulig å opprette én slik eksklave til. Det er imidlertid ingen grunn til å tro at dette vil bli godtatt av russiske myndigheter, enn si av det internasjonale samfunn. 
Gjeninnlemmes i utfordrerstaten som egen autonom enhet i et føderativt eller konførativt arrangement.

Ofte vil dette være den beste kompromissløsningen, og var mer er: I forhandlinger mellom en kvasi-stat og en utfordrerstat gir gjerne begge parter i prinsippet sin støtte til et slikt arrangement. Dette gjelder for eksempel Dniester-konflikten og Kyproskonflikten. Likevel har det etter årevis med forhandlinger ikke vært mulig å finne frem til omforente løsninger i noen av disse tilfellene. Kypros-forhandlingene er riktignok helt i det siste kommet ut av dødvannet i forbindelse med det forestående EU-medlemskap for Kypros. Den nye tyrkiske regjeringen i Ankara presser på for at Rauf Denktash og de tyrkisk-kypriotiske myndighetene skal vise større fleksibilitet. Det gjenstår likevel å se om dette vil kunne føre til en varig løsning.

Når mange forhandlinger om kvasi-statenes status står i stampe, kan det selvfølgelig skyldes at dette dreier seg om kompliserte spørsmål og mange detaljer som skal på plass. Dersom dette er hovedgrunnen, vil en løsning til syvende og sist bli funnet når partene bare får nok tid på seg. Men mange observatører sitter med en bestemt følelse av at det nok også kan skorte på forhandlingsviljen, kanskje fra begge sider, men især fra kvasi-statens side. Dette gjelder både PMR, Abkhazia og Nord-Kypros. Samtidig som kvasi-statens ledere helt klart oppfatter status quo som lite gunstig sammenlignet med det optimale ønske, som er egen, anerkjent stat, så foretrekker de likevel å fortsette som kvasi-stat fremfor å bli innlemmet i utfordrerstaten qua autonomt område. Enkelte kvasistatledere kan nok har et genuint ønske om å nå frem til en avtale med utfordrerstaten, men de blir kraftig motarbeidet innenfra, fra kriminelle og halvkriminelle elementer i kvasi-staten selv. Som jeg har påpekt nyter disse godt av kvasi-statens uavklarte og ugjennomsiktig status, og går imot enhver endring som vil 
bringe området inn under internasjonale kontrollordninger. I tilfellet Republika Srpska i Bosnia-Herzegovina ble denne løsningen til slutt godtatt kun gjennom massivt internasjonalt press, militært og diplomatisk.

\section{Oppnår full uavhengighet}

For de aller fleste kvasi-stater er full uavhengighet og internasjonal anerkjennelse åpenbart den optimale løsning, og noen har allerede nådd dette målet. Litauen fungerte som en kvasi-stat fra mars 1990, da det litauiske Øverste sovjet proklamerte full politisk uavhengighet for republikken, frem til landet ble internasjonalt anerkjent i august året etter. Litauen vil meget snart bli medlem av både NATO og EU. Landet er selve kroneksemplet på en vellykket overgang fra kvasi-stat til 'normal' stat, og tjener slik som inspirasjonskilde for andre kvasi-stater.

Også andre områder har foretatt en relativt vellykket overgang fra kvasi-stat til normal stat. Dette gjelder blant annet Makedonia, som på mange måter var inne i en uhellsvanger utvikling i den tiden landet fungerte som kvasi-stat, frem til 1993. Etniske spenninger bygget seg opp og kriminelle elementer fikk fotfeste. Etter at landet ble internasjonalt anerkjent har landet langsomt kommet inn i et bedre spor, selv om de gamle problemene på ingen måte er løst.

Det er likevel ingen grunn til å tro at alle kvasi-stater automatisk vil klare overgangen til 'normal' stat bare de blir anerkjent. Som allerede påpekt har mange kvasi-stater en økonomisk og institusjonell struktur som ligner det man finner i Jacksonske 'quasistates.’ Det er gode grunner til å anta at dersom disse statene blir anerkjent av verdenssamfunnet som en slags belønning for de lidelser de har måttet utholde så 
lenge de var undertrykt av utfordrerstaten, vil mange av dem fort kunne endre opp som nettopp 'quasi-states' snarere enn som vel-fungerende stater. Det kan gå godt, slik det makedonske og eritreiske tilfellet ser ut til å vise, men det er ingen grunn til å anta at disse landenes erfaringer uten videre kan overføres til f.eks. Tsjetsjenia, SørOssetia, Nagorno-Karabakh, Nord-Irak eller Kosovo. Dersom det internasjonale samfunn skulle bestemme seg for å anerkjenne noen av disse selverklærte statene, da bør det også belage seg på å gi massive tilskudd til oppbygging av effektive statstrukturer, kombinert med tett oppfølging og kontroll i mange år fremover. 